\title{
THE ROLE OF YOUTH PARTICIPATION ON GOOD GOVERNANCE AT TWO SELECTED YOUTH ORGANIZATIONS IN MOGADISHU, SOMALIA
}

\author{
Ali Abdi Sheikhdon \\ Lecturer Department Education \& Humanity at university of Somalia
}

Article DOI: https://doi.org/10.36713/epra6004

\begin{abstract}
The purpose of this study is to evaluate the role of youth participation on good governance of two selected youth organizations in Mogadishu, Somalia.The objectives of the study are to determine the role of youth participation in good governance, to find out capacity building as catalyst for good governance and how the youth organization can spur youth leadership in the country To achieve the objectives of this study, data will be collected from 82employees of youth organizations. A sample size of 68 respondents was selected using Slog van's formula. The study will use primary data. Data collection methods use included use of questionnaires. The selection sample technique will be purposive or judgmental approach. Data will analyze using SPSS version 16 for productions of tables, descriptive statistics and inferential statistics. E.g. means, standard deviation, frequencies. Inferential statistics such as Regression Analysis were used for further analysis. Findings: The study has three objectives which are: To determine the effect of capacity building in good governance at two selected organizations, in Mogadishu, Somalia. To find out the effect of political participation in good governance t at two selected organizations, in Mogadishu, Somalia, To establish the effect of youth leadership in good governance at two selected organizations, in Mogadishu, Somalia. After analyzing the data, the study found that there is positive relationship among all variables as following: $R$ is the correlation coefficient which shows the relationship between the study variables. From the findings shown in the table above there was a strongly positive relationship between the study variables as shown by 0.815 . Overall, Political participation had the greatest effect on the good governance of youth organizations in Mogadishu, followed by Youth leadership and capacity building. All of the variables were found to be significantly affect good governance of youth organizations because they less than $(p<0.05)$. Recommendation: organizations should implement good strategies for support management system of administrative reform on education management. organization should promote their beneficiaries to better satisfy as to achieve to education management. Promote the concept of young people as assets and work towards the elimination of negative stereotypes of youth. Promote the full and effective participation of young people at local, national, regional and international levels, with particular attention to marginalized youth. Youth participation can also be improved through a number of approaches, such as education and capacity building.
\end{abstract}

KEYWORDS: Youth Parturition, Capacity Building, Political Participation, Youth Leadership \& Good governance.

(c) 2020 EPRA ARER ｜ www.eprajournals.com ～Journal DOI URL: https://doi.org/10.36713/epra0813 


\subsection{INTRODUCTION}

The term youth participation refers; to the youth taking part or having a share in the development projects in the community. According to Armitage (2010), participation is defined as a process where the youth acts in response to the concerns of the public, raise their opinions on the decisions that affects them and thus take responsibility for the changes that affects them and the entire community. The youth participation according to Chappel, (2008) the youth participation could be as a result of the traditional sense powerlessness felt by the community especially the youth when it comes to participating in the decision making processes in the government decisions. There are various definitions for the youth therefore the definitions depend largely on the context and who is defining the term. A number of organizations have different definitions based on their contextual approach. The United Nations (UN) defines youth as a person who is between 15 and 24 years Armitage (2010).

The task of youth participation has been argued to be historically contingent due to the fact that the process is inextricably tied to the formation, growth and demise of nations as well as factors that influence the process (Oghi \& Ajayi, 2011). The attempt at integrating the diverse elements in a country in order to promote a sense of belonging among people is also part of nation building process (Wallenstein, 1961). Nation building therefore, involves not only the implementation of political and economic policies that will improve the lives of the citizenry, but also a recognition of values and other aspects of the state that would act as a national catalyst to bind the people (Elaigwu, 1983). Culture, which is the totality of a people's way of life, is crucial to nation building because its non recognition could promote fissiparous tendencies among the citizenry. According to Wikipedia (2013), Nationbuilding refers to the process of constructing or structuring a national identity using the power of the state(Elaigwu, 1983).

This process as Eme and Onyishi (2014) noted aims at the unification of the people within the state so that it remains politically stable and viable in the long run. Nation-building can involve the use of propaganda or major infrastructure development to foster social harmony and economic growth. It is also the development of behaviours, values, language, institutions, and physical structures that elucidate history and culture, concretize and protect the present, and insure the future identity and independence of a nation. For the purpose of this presentation, youth participation is viewed as purposeful interventions in the affairs of a nationstate for the purpose of changing the state's method of governance. It includes deliberate efforts to promote institutions which will provide for a people's enhanced economic well-being and social equity Onyishi (2014).

Masanyiwa and Kinyashi (2008) in a study in Tanzania observe that community members participate effectively when they perceive that interventions being undertaken by a project address their immediate needs as identified in community consultation processes. Further, Bhatnagar and Williams (1992) observe that people support and participate in projects that account for their needs. Beneficiary communities participate collectively to take initiative for their own socio-economic development which results in empowerment through asset and capacity building. People's participation can be based on the fact that people have the ability to carry out activities suited to their needs by becoming empowered to develop them in a collective effort to improve living conditions in the community which is dependent on the people determining their wants and needs and how to do it (Samah \& Aref, 2009). The study findings therefore indicate that in the community driven development approach, development interest, project meets needs, previous development experience, to serve the nation building and development need contributes to participation by beneficiary country in development Kinyashi (2008).

In Africa has sustained the confusion surrounding this concept. The perception of youth varies culturally and historically, from one context to another and even within contexts (Chigunta, 2006; United Nations, 2003). According to the World Youth Report (2003), the UN definition of youth is 15 to 24 years, while the Commonwealth definition stands at 15 to 29 years; the African Union adopts a broader definition of 15 to 35 years. But for many scholars, youth is better defined as that period of transition from dependence (childhood) to independence (adulthood), the nature and length of which varies from one individual or society to another (Curtain, 2003).

The transition definition of youth has also been proposed. Rather than defining youth on the basis of age groups, within this definition, youth can be understood as a socially constructed category defined by societal expectations and responsibilities (Honwana and De Boeck 2005). For this study, the term 'youth' is framed around the African Union definition, that is, people aged between 15 and 35 years old. However, the term 'youth' will include people who may not meet the African Union definition but who are regarded as youth in their respective societies and contexts. For the purposes of this study, elders are therefore defined as people older than 35 years old or generally regarded as elders in their respective societies and contexts. Youth participation therefore is youth involvement in participatory governance, where participatory governance is held as the ample opportunities democratic governance offers citizens and their 
organizations to engage with government (Fioramonti and Heinrich, 2007) .

According to Yale University political scientist Robert Dahl, such ample opportunities democratic governance offers include effective participation, voting equality at the decisive stage, enlightened understanding, control of the agenda and inclusiveness (Dahl, 1991). Quiet participation refers to the involvement in everyday processes of social change by fashioning the spaces within which the youth try to get by, 1 Adapted from source: www.civicus.org/what-we-do/priority-

areas/influence-of-civilsociety/pg-project Field Code Changed MINDS Annual African Youth Dialogue 2015 Discussion Paper 7 leaving the task of governance to the elders. Asef Bayat calls these dispersed options "non-movements," which he describes as "quiet and unassuming daily struggles" outside formal institutional spheres in which everyday social activities are called political activism (2010: 5).

This leads to the notion of active participation. According to the UN World Public Sector Report 2008:4, "active participation" means "the involvement of citizens in a wide range of policymaking activities, including the determination of levels of service, budget priorities, and the acceptability of physical construction projects in order to orient government programs toward community needs, build public support, and encourage a sense of cohesiveness within neighborhoods." Active participation is linked to direct/ effective participation which the UN Conference on Sustainable Development (or Rio+20) qualifies as a participation "representing the voices and interests of all." While UN uses the concept 'direct/effective participation', it does not, so far, define it. In his book Democracy and its Critics Robert Dahl defines effective participation as citizens unconditionally having equal opportunities to form their preference and place questions on the public agenda and express reasons for one outcome over the other (Dahl, 1991:221). Chapter two tracks the background of youth participation in governance, the concept of "waithood" (in the African context) and its attendant burden, as well as the broad categories of youth participation in governance today.

In Somalia youth hold the potential to contribute to positive change in their country. However, currently they are also the majority of the participants in militant and criminal groups. To better understand the drivers of youth violence in Somaliland and Puntland, Mercy Corps Somalia examined the links between economic opportunity, civic engagement and conflict as part of its USAIDfunded Somali Youth Leaders Initiative.(Mercy Corps, 2013)

During the first development decades of the 1950 s and 1960s, nation building (NB) was actively promoted throughout the developing world as part of the state building process and as a means of raising standards of living by governments and by the United Nations through its affiliated institutions as part of independence and decolonization movements in Africa (Briggs et. al.,1997). During this period, nation building programs were established by the state to mobilize people in the local communities. Wharf (1999) notes that in Anglophone Africa, nation building during the first half of the twentieth century was informed by the dominant modernization development theory. Provision of infrastructure was perceived as the means of modernizing the so - called primitives of the less developed realm of the world. Hence, the Gold Coast government initiated steps in the early 1940 s to promote nation building Wharf (1999).

Through literacy education and adult education, nation building became a useful instrument for extension campaigns. Hence, extension campaigns introduced new and improved techniques designed to enable people, to improve their general standard of living through their own efforts (Sautoy, 1960). Other government agencies adopted this approach as well. In 1953 the Department of Agriculture asked nation building staff for help in disseminating information on rice growing, the use of fertilizer, and the production of manure for mixed farming. Also, workers were taught adult education techniques and the principles and practice of nation building. For example, they learned agriculture, basic building techniques, and the use of visual aids. In addition, rural training centers in the country provided refresher courses.

Youth participation in community development activities can be beneficial for both the community and youth development. Young people can bring innovation, creativity and energy which can be useful in community development. Community development involves the mobilization of members in efforts aimed at socio-economic development (O"Brien, 2009).

Youth participation can thus be seen as an ideal strategy for nation building. The emerging global and regional consensus on youth development clearly underscores the need to ensure the inclusion of youth perspectives in the development process along with the effective participation of youth in nation building practice, Over the years, there has been a gradual increase in global awareness about the vital role of young people in sustainable development, The United Nations in 1985 drew the attention of the world to the important role of young people by declaring that year, The International Youth Year for Development and Peace. (Giwa, 2008)

In Somali youth are faced many problems including empowering the youth through education is exceptionally worthwhile as education is a strategic investment in human resource with high social returns and acts as a facilitator in almost every aspect

(c) 2020 EPRA ARER ～～www.eprajournals.com ～Journal DOI URL: https://doi.org/10.36713/epra0813 
of development. Education has become one of the key development objectives in recent times. School dropout is a social canker that many governments seek to redeem. Most government policies including free and compulsory primary education, capitation grants, the school feeding programme and other policies were instituted into the country for nationwide benefits. Despite all these measures, the foundation of school dropout is enlarging. Therefore, this study sought to the role of youth participation in education development in Mogadishu-Somalia

\subsection{SPECIFIC OBJECTIVES}

I. To determine the effect of capacity building on good governance at two selected of youth organizations in Mogadishu-Somalia

II. To find out the effect of political participation on good governance at two selected of youth organizations in Mogadishu-Somalia

III. To establish the effect of youth leadership on good governance at two selected of youth organizations in Mogadishu-Somalia

\subsection{LITERATURE REVIEW}

The purpose of this study was being to examine the role youth participation on good governance at two selected of youth organizations in MogadishuSomalia

\subsection{CONCEPT OF CAPCITY BUILDING}

Before defining capacity building, it is necessary to understand the meaning of the words „capacity" and „capabilities". According to Frank (1999, cited in Hussein, 2006), there is a difference in meaning between capacity and capability. Capability is defined as the knowledge, skills and attitudes of individuals. In contrast, capacity is defined as the general ability of individuals or organizations to carry out the responsibilities required to achieve their goals. Baser and Morgan (2008) referred to capacity as the collective skill and ability of organizations to achieve a particular process either inside or outside the organization. Goodman et al. (1998 cited in LaFond \& Brown, 2003 p. 7) pointed out that capacity is "... the ability to carry out stated objectives Mokta (2005)."

Capacity can include "hard" attributes (e.g. personal skills, functions, structures, infrastructure and resources) and "soft" attributes (e.g. motivations, beliefs) (Land 2000, cited in Hunt, 2005). Hinings and Greenwood (1988, cited in Stevens, n. d) stated that "capacity relates to the capabilities and competencies of an organization....the capacities and competencies of an organization include leadership and knowledge 16 components, as well as technical knowledge and skills." Capacity is the power or ability of something - a system, associations, groups or individuals - to conduct and produce appropriately (UNDP, 1997). Capacity is the people, institutions and practices that enable countries to achieve their development goals and it is a key factor in development (World Bank, 1997). Capacity refers to an organization's ability to achieve its mission effectively and sustain itself over the long term. Capacity also refers to the skills and capabilities of individuals (Linnell, 2003, p.13). According to Honadle (1986, p. 10) "„,capacity" also means the ability of an organization to be self-sustaining". Brinkerhoff (1995 cited in Melen 2001, p. 4) believed that "capacity is an instrument for an individual, team, organization or system to achieve objectives". Melen (2001) stated that the ability of individuals, groups and organizations to establish and implement development objectives on a sustainable basis all contribute to sustainability. Therefore, the term capacity has a variety of different meanings and translations depending on who uses it and in what situation (Enemark, 2003). The head of one of the key NGOs working in Laos stated that: Capacities cannot be handed over from outside. They must be developed from within, even if knowledge from outside is a key for development of capacities. (Country Director of SNV (Organization of Netherlands Volunteers), 2004 cited in Stephen, Brien \& Triraganon, 2006, p. 27)

The concept of capacity has been broadened to include the building of capacity. As Hilderbrand (n. d, p.39) stated; Capacity is the "mean", or the ability, to fulfil a task or meet an objective effectively... and capacity has often been used in a narrow sense to refer only to the skills of staff and strength of 17 specific organizations; thus, training staff and creating or strengthening single organizations is equated with capacity building. Capacity building means a new build-up of capabilities (Kuhl, 2009). Capacity building is a concept that has different meanings for different people, but in general relates to enhancing or strengthening a person's or organization's capacity to achieve their goals (Lusthaus, Adrien \& Perstinger, 1999). Capacity building also increases the abilities and resources of persons, communities and organizations to manage change (Coutts, Roberts, Frost \& Coutts, 2005). Capacity building refers to activities that improve an organization's ability to achieve its mission or a person's ability to define and realize his/her goals or to do his/her job more effectively (Linnell, 2003, p.13). Capacity building is as important as capital investment and infrastructure (Mati, 2008, p. 339). UNESCO (2006) reports that capacity building focuses on increasing an individual and organization's abilities to perform core functions, solve problems, and objectively deal with developmental needs. This is supported by Morgan (1997, cited in Horton 2002) who referred to capacity building as improving or upgrading the ability of the person, team and institutions to implement their functions and achieve goals over time. Capacity building is important for all levels, from individuals

\footnotetext{
(c) 2020 EPRA ARER ～～www.eprajournals.com ～Journal DOI URL: https://doi.org/10.36713/epra0813
} 
to national organizations (Horton, 2002). Capacity building also alludes to building the organizational capacities of communities, and supports the formation of non-profit organizations (Paul \& Thomas, 2000).

Capacity building must promote a better understanding of the relevance of biodiversity for the sustainable and equitable use of biodiversity resources (UNEP/UNESCO, 2012) and develop actions to prevent the deterioration of ecosystems in order to ensure their use (Ehler et al., 2007; Pomeroy \&Douvere, 2008). This new vision requires foreseeing human society not as the dominator of its environment but as part ofit (Novo, 2009). It also considers the environment globally(e.g. natural and built, technological and social), drawing on specific contents of diverse disciplines in developing a holistic and balanced approach Sinha et al. (1985).

In 1970 the IUCN defined environmental education as "the process of recognizing values and clarifying concepts in order to develop skills and attitudes necessary to understand and appreciate the inter-relatedness among humans, their culture and biophysical surroundings" (Hesselink \&Cerovsky, 2008). Education is an opportunity for building citizenship and empowering political institutions, which requires developing new skills, e.g. to express demands and opinions in the media, to participate in network systems, and to adapt to situations of increasing flexibility. Environmental education needs to be problem atized by debating the relationships between society and nature (da Silva \& Rainha,2013). This challenge requires a broad participation of stakeholders, particularly of local agents assuring innovative solutions towards environmental sustainability (Martínezet al., 2007). These key players are then able to promote articulation mechanisms among stakeholders. Some writers identify that capacity can drain from 'community' whether through influences outside or within 'communities', or because of the conditions and time limitations of government funded capacity building projects. In some accounts cited in this literature community members have reported decreased local or community capacity due to 'burn out' and cynicism, especially in the face of shortterm funding, high expectations and unresponsive institutions. Some writers call for more attention to this issue. A number of authors raise the implication that the language 'capacity building' implies a 'lack of' capacity and that this can be viewed as negative, patronizing and paternalistic (Appalachan Regional Commission; Hunt, 2005).

Writers like Susan Kenny (2001) suggest that the contemporary language of capacity building is emblematic of a 'fused discourse' where seemingly dissimilar ideas are melded and held together in union. For instance, market/private responsibility and individual obligation with communal action; business entrepreneurship and community development; local control with increased regulation; long-term visions realized in short time periods. Kenny and others suggest this generates new paradoxes for community workers and she uses the metaphor of 'a Trojan horse' to depict this. Others contend that this 'fusing' is not a new phenomena but rather the old paradoxes of community development/capacity building are intensified in a world of rapid social change Mokta (2005).

Capacity building has also been described as 'exciting', 'innovative', 'empowering', 'significant' and 'new'. Proponents of the construct point to emerging research evidence that 'community capacity building' can support community based empowerment; the development of skills, knowledge and resources; strengthened social relations; support health gains and stronger links between policy environments/communities/ organizations. In the words of Chapman and Kirk it can promote the preconditions for 'community development in the long term' (2001).

Capacity building is frequently pegged to efforts to redress disadvantage, health promotion, social and urban improvement and foster social change goals (Smith et al, 2001; Hawe et al, 1997; Hounslow, 2002). Building community capacity is also associated with a series of techniques and practices, and in various accounts, it is stitched together with other notions of social capital, community competencies, asset based social planning and social participation Mokta (2005).

An underlying idea informing community capacity building is that improvements and solutions to 'community problems' can, and should be, 'un leased' from within communities rather than imposed from outside- whether through the market, state institutions, or 'experts' with little affinity to the issues facing the community. These communitarian ideas have been influential in both New Right and Third Way politics as Giddens notes (2000:62).

According to Adams et al. (2007), between the 1960s and 1970s, developing countries lacked experience in administration. Capacity was seen to be limited as a result of lack of sufficient skills and development experience of public servants. Therefore, rural development focused on delivering management courses to public servants, and providing training to aid-administrators. The educational methodology gradually changed from training courses to workshops, from teaching to sharing experience, and from instructing to facilitating. From the 1980 s onwards, supporters or donors changed their emphasis from persons to groups and organizations, building the capacity of local associations to carry goods and services stipulated in aid contracts. However, on the practical side, donors continued to use the same methods such as training and workshops. From the 1990 s, the idea of capacity building was developed and accepted by development organizations and has become an

(c) 2020 EPRA ARER | www.eprajournals.com ～Journal DOI URL: https://doi.org/10.36713/epra0813 
approach to development. The emphasis is on increasing the knowledge, skills and ability of people at various levels to be more effective in their work Mokta (2005).

Capacity building has been tagged as a 1990s and early 21 st century notion and practice (Criag, 2007). In respect to health promotion, Hawe et al (1998), suggest that it emerged in the early 1990s and they draw attention to its place in the Jakarta Declaration of Health Promotion. Mowbray (2004) also pegs it as a 1990s development and one that is intertwined with a more widespread adoption of communitarian ideas. This term 'communitarian' refers to values and ideas wherein 'community' is considered to meet individual and social needs, provide services, empower people and engender social 'good/s' more beneficially than the 'state'. For example Chapman and Kirk (2001:9) writing about the United Kingdom, note that community capacity building is embedded in New Labour policies to address social exclusion, stimulate urban regeneration, build social cohesion and extend quality services and processes Mokta (2005).

\subsection{CONCEPT OF POLITACAL PARTICPATION}

Although the study of political participation plays a central role in many political science studies, the meaning of the concept itself is disputed. To explain how political participation is understood in this study and which activities I have chosen to include under this heading, I therefore first give an outline of how scholars have interpreted and modified this concept over time and briefly review the main debates on which activities should be recognized as political participation. I then present the interpretation I choose to adopt Kaase (2008).

Although voter turnout remains the activity most readily associated with the study of political participation, the variety of acts undertaken by citizens to influence politics is actually much more diverse and can include, for example, party activism, signing a 1 petition, attending a demonstration, contacting an official or wearing a campaign badge. Faced with such a wide range of potential activities, various significant attempts have been made by researchers to categories these. The classic typology used in the seminal studies of participation by Verba and Nie (2007) and Barnes and Kaase (2008) distinguished between conventional and unconventional participation. These categorised activities conducted through official channels such as voting or party activism as conventional and others, organized outside such channels such as demonstrating or occupying a building, as unconventional.

However, the continued relevance of this distinction has been questioned by more recent studies of political involvement in established democracies. For instance, Norris (2003) argues that, in recent decades, the ways that citizens choose to interact with politics have changed significantly. These changes, she claims, are evident in the repertoires (types of participation), agencies (the organizations through which citizens participate) and the targets (who or what the participant aims to influence) of political participation.

For Norris and others (Verba et al. 1995, Van Deth 2001, Van Deth et al. 2007) this has meant that the distinction between conventional and unconventional participation has become increasingly blurred. In the past unconventional participation was seen to be activity undertaken by a rebellious few against actions by the state. Yet nowadays protest activities such as boycotting and demonstrating have become much more widespread (Tarrow 1998, Putnam 2000) and have a much larger range of potential targets which may include local businesses and international organizations as well as seeking to influence public opinion and behaviour (Norris 2002, 2003). At the same time, the agencies of participation have also become much more diverse. New technology, in particular, offers opportunities for communication and organization which were unavailable a few decades ago.

Notions of the 'political' sphere within which participation takes place have also required rethinking. In their study of democratic consolidation, Linz and Stepan (1996), make a clear distinction between political society which constitutes the 'core institutions' of 'political parties, elections, electoral rules, political leadership, interparty alliances, and legislatures' and economic and civil society. According to this rigid distinction, only those activities which are overtly 'political', in that they are plainly directed towards influencing state policy, would fall under the heading of political society. However as discussed above, many activities in which citizens engage are not directly related to political parties or elections but may still aim to influence political decision-making. These 'overlaps' between political and civil society have been recognized to different degrees by scholars (Potter et al. 1997, Millard 1999).

Howard (2003. pp.32-38), for example, distinguishes between political and civil society asked on both the character of the actors and aims of various organizations. He argues that political society is mainly made up of elite actors and institutions while civil society is the 'realm of ordinary citizens' and that although civil society organizations may also seek political influence, unlike those in political society their main goal is not to gain political power. Despite this, he does nonetheless acknowledge a 'small but significant overlap' between the two groupsHoward (2003).

Thus, although he places organizations such as youth groups and community groups firmly within civil society, political parties, political interest groups and NGOs can be found in both civil and political

(c) 2020 EPRA ARER ～～www.eprajournals.com ～Journal DOI URL: https://doi.org/10.36713/epra0813 
society. Although such a distinction between civil and political society may be useful for studies of civil society, it has less value for political participation research. This is because attempting to delineate political society and civil society effectively excludes many activities from being seen as forms of political participation by placing them under the heading of civil society. For instance, under this distinction, many contrasting organizations can be grouped together as civil society organizations (Norris 2002, 2003).

\subsection{CONCEPT OF YOUTH LEADERSHIP}

The 21 st century has experienced an immense growth in the interest for studying youth leadership (Hunter et al., 2007). Leadership is one of the most attractive research subjects. In order to classify the vast majority of literature three types of variables have been emphasized: (1) characteristics of leaders such as traits, skills and expertise, behavior, ethics, influence tactics, attributions about followers etc., (2) characteristics of followers, such as traits, confidence and optimism, skills and expertise, attributions about the leader, trust in the leader, task commitment, effort, job satisfaction etc., and (3) characteristics of the situation, such as type and size of organization unit, task structure, complexity, and interdependence, external dependencies etc. (Yukl, 2006).

This study focuses on examples from the first and the second group: the skills, behaviors and influence tactics of the leader, and also on followers' trust in the leader, task commitment, effort, job satisfaction. It studies leadership from subordinates' perceptions of their supervisor's behavior, and how this behavior affects subordinate actions or perceptions, resulting in some kind of desired outcome. This is done even though, as a matter of fact, subordinates are not able to observe their supervisor's every activity, since supervisors quite often have meetings with other leaders, clients etc., when they are not witnessed by subordinates. Hence there will inevitably be flaws and short-comings in this approach to leadership studies, and the findings may not be totally reliable (Hunter et al., 2007). Also, this study falls within the tradition of dyadic leadership research (Yukl, 2006), studying relationships between the leader and the follower Mokta (2005)r.

According to Yukl (1989), youth leadership includes consulting with subordinates, taking into consideration their thoughts and opinions. Frontline hotel employees are more familiar with customer needs than managers due to direct contact with guests; therefore participation of the employees in the decision-making process is for the benefit to the management (Clark et al., 2009).

Conger and Kanungo (1988) define youth leadership as a process where subordinates are given the authority and independence to make decisions regarding customer needs without consulting a supervisor. Empowering leadership is the most transformational. The autonomy in the decision making is necessary for effective service (Clark et al., 2009). Job satisfaction often results in better service quality provided by the employees to the customers, which is very important in hospitality industry. Directive leadership, in contrast, diminishes job satisfaction. Empowered employees tend to be more satisfied with their jobs because they have more control about what they are doing (Clark et al., 2009).

There has been a sporadic growth in the interest of youth becoming more involved in the communities in which they live. Although a growing body of literature has promoted youth leadership, there remains limited empirical evidence of how youth benefit from serving as civically-engaged leaders to address community issues. Most of the existing data is a result of qualitative procedures used to explore the youth-adult partnering phenomenon (Camino, 2000; Larson, Walker, \& Pearce, 2005). A few studies have found that youth develop leadership skills, social skills, and life skills (Checkoway, et al., 2003; Israel \& Ilvento, 1995; Lerner, Dowling, \& Anderson, 2003; Perkins \& Borden, 2003; Zeldin, McDaniel, Topitzes, \& Calvert, 2000) and communities also benefit from the endeavors set forth by such partnerships (Sandefur \& Laumann, 1998). However, more studies that take a longitudinal approach to investigating youth leadership development over time are needed Mokta (2005).

This study examined which of the factor (social media, social groups or government policies) most influences youth's ability to participate in leadership in Malaysia. Using a conceptual framework, and social impact theory, the study aimed to investigate the possible reasons why most Malaysian youths at secondary and tertiary educational institutions do not actively participate in leadership activities in their communities. The study employed cross-sectional survey and proportionate stratified random sampling method to collect data from 310 youth leaders in north, east, west and south zones of Malaysia peninsula. However, after data cleaning, data for 141 respondents were analyzed through descriptive statistics and regression methods. Among others, the study found that social media (use time), and social groups (mentors) have the most significant positive effects on leadership participation among Malaysian youths. The study, therefore, recommended that the government and the universities management should monitor and restrict information transmitted on social media to forestall negative social influence on youths by mentors. This could lead to greater participation in leadership activities among Malaysian youths.(Ekpe, 2017)

As future leaders, the role of youths in the political and socio-economic development of a country is vital as they are considered the active working group (Aminu, 2012). Therefore, to develop

(c) 2020 EPRA ARER ～～www.eprajournals.com ～Journal DOI URL: https://doi.org/10.36713/epra0813 
their mindsets towards this role and empower them to contribute to informed decisions about their personal, family, social and political development, they need to participate in current leadership activities in their communities, irrespective of their social background. Such participation would afford the current leaders an opportunity to respond to the needs of the youths and guaranty their fundamental human rights. It would also afford the youths an opportunity to work with the adults and peers on sustainable basis (Ahmad et al., 2012). For example, youth's involvements in extracurricular activities are vital elements of community involvement in leadership (Barnett and Brennan, 2006).

\subsection{CONCEPT OF GOOD GOVERNANCE}

Good governance is the "use of power in the management of a country's economic and social resources for development"[The World Bank (1992). It can also be defined (UNDP, 1997) as "the exercise of political, economic and administrative authority to manage a domestic affair". The UNDP (1997) identifies four types of governance. The first is economic governance. This includes the processes of decision making that directly or indirectly affects a country's activities or its relationships with other economies. Economic governance has a major influence on societal issues such as equity, poverty and quality of life. The second is political governance. It refers to decision making and policy implementation of a legitimate and authoritative state. The state should consist of separate legislative, executive and judicial branches; represent the interests of a pluralist polity; and allow citizens to freely elect their representatives (Pierre and Peters, 2000).

The third type is administrative governance - a system of policy implementation carried out through an efficient, independent and open public sector. The fourth is systemic governance, which encompasses the processes and structures of society that guide political and socio-economic relationships to protect cultural and religious beliefs and values, and to create and maintain an Environment of health, freedom, security and with the opportunity to exercise personal capabilities that lead to a better life for all people. Improved antidomestic governance is an important instrument to make globalization sustainable. Closer and more practical cooperation is needed among all antidomestic organizations, especially those concerned with trade, the environment and development. The Summit should encourage the World Trade Organization (WTO) committees on trade and environment, and trade and development, to implement commitments made under the Doha ministerial declaration aimed at benefiting domestic development (Pierre and Peters, 2000).

Good governances are two concepts intimately tied together. Good governance does not guarantee sustainable development; however, its absence severely limits it and can, at worst, impede it. In this generous context of analysis, we bring into discussion how and to what extent good governance can support domestic development and is reflected in domestic development strategies. This subject, of great interest for scientific community and policy makers, is obviously extensive and complex and needs to be approached from different perspectives. The paper cannot and does not attempt to offer answers to all questions, rather it sets a stage for discussion, exploring some of the many ways in which governance is used in connection with domestic development strategies. The paper is structured in two parts. The first part is dedicated to present some theoretical considerations regarding governance and its relation to sustainable development. The second part approaches a research about the reflection of governance in European Union (EU) countries domestic development strategies, using as methodology the thematic content analysis. The paper ends with a section of conclusions regarding highlighted by the empirical research, with implications for further research (Pierre and Peters, 2000).

\subsection{SUMMERY}

Youth empowerment derives from power, an understanding that involves the capacity of people and organizations in terms of personality or wealth to control others or events (Galbraith, 1983). Cornell Empowerment Group (1989) defines empowerment as an intentional ongoing process entrenched in local communities, engendering mutual respect, critical reflection, caring and group participation whereby disadvantaged people gain greater access to and control over resources (Cornell Empowerment Group, 1989). There are differences among researchers on attributes of empowerment, however both processes and outcomes are significant factors, and collective decision making, shared leadership and situation specific control, all contribute to the degree of empowerment (Zimmerman, 1993; Rappaport, 1984; Swift and Levin, 1987).

The academic literature on governance, good governance and domestic development governance has grown rapidly. However, apart from the universal acceptance of its importance, differences prevail in respect of theoretical formulations, policy prescriptions and conceptualization of the subject itself and no one can claim ownership of the Governance however modern theories have expanded the connotation, focusing on a large variety of instruments designed to alter and channel the behavior of individual and collective actors (Loorbach, 2007; Pierre and Peters, 2000; Adger and Jordan, 2009). 


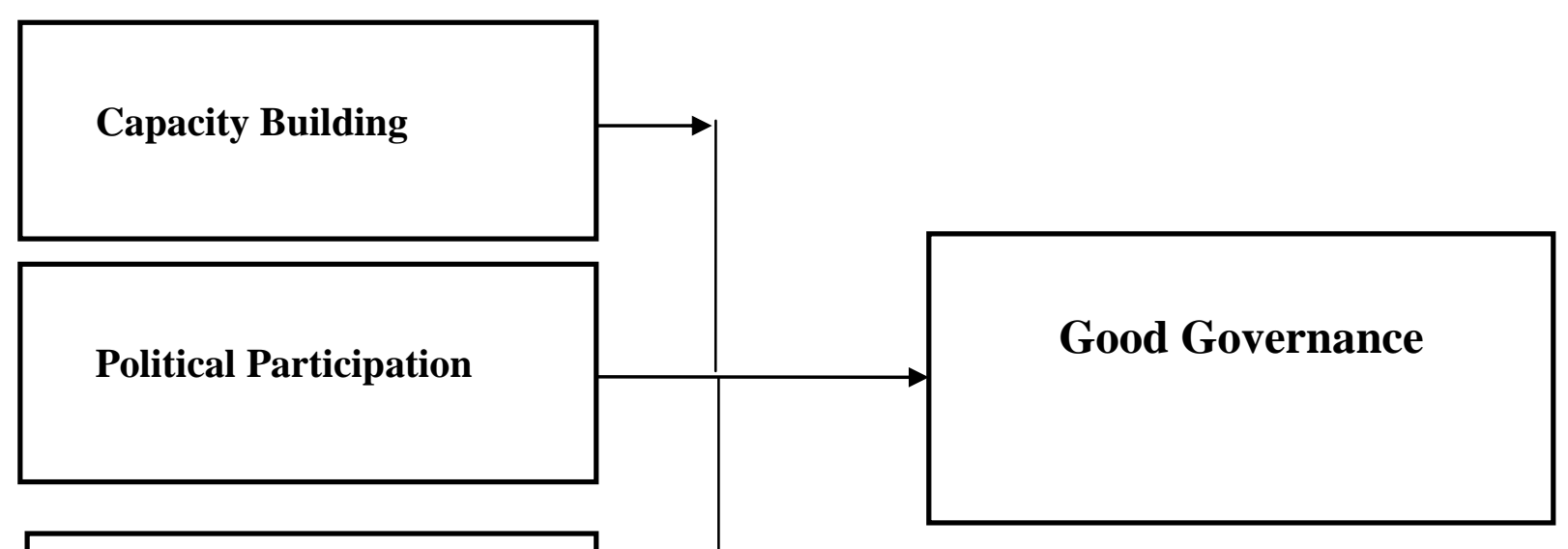

Youth Leadership

\subsection{METHODOLOGY}

A Cross sectional study focuses on the research design and the concern of addressing the particular characteristics of a specific population which is under-course of subject, either at a fixed point in time or at varying times for comparative purposes an example, the researchers do not share the emphasis in analytic designs upon control but they do share a concern to secure a representative sample of the relevant population. Quantitative research methodology was appropriate for this study because the researcher wanted to hear anecdotal accounts from the participants. The researcher also wanted to focus on the school environments under study because human behavior does not occur in an empty space. Strewing and Stead (2004) point out that contextualize stresses the various macro and micro contexts of the individual and how these contexts dynamically interact with one another. Furthermore, these authors state that contextualize is closely aligned to holism which examines social environments in their totality.

The target population of this study will be conducted 82 employees of two youth organizations in Mogadishu, Somalia, who represented on all youth organizations and their members. Somali Youth Club (SYC), Somali Youth Development Centre (SYDC) and they are a good source of information to analyze the topic. Burns \& Grove (2003) states that population includes all elements that meet certain criteria for inclusion in a study.

Sampling is the process of selecting a number of individuals for a study. A sampling design is a defined plan determined before any data is collected for obtaining a sample from a given population. The selected number of individuals will be as a representative of the whole population under study.
The formula which will used this study was Slog van's formula which states the sample size of employee in two youth organizations in Mogadishu. The main objective of using this sample will to obtain accurate and reliable information within minimum cost, time and energy.

The sample consists of 68 employees of Somali Youth Club (SYC), Somali Youth Development Centre (SYDC) in Mogadishu according the slog van's formula, which states:

$\mathbf{n}=\mathbf{N} \div\left[\mathbf{1}+\mathbf{N}\left(\mathbf{e}^{2}\right)\right]$ Where: $\mathrm{n}=68 . \mathrm{N}=82$, e $=$ marginal error

Non-probability sampling (or non-random sampling) provides a range of alternative techniques to select samples based on your subjective judgment (Saunders et al., 2009). The researchers will use judgmental sampling techniques of non-probability sampling because the researchers cannot obtain the list of Youth organizations of employee. Therefore, data will be collected from those people who are conveniently available and willing to co-operate. Purposive sampling was also convenient because the sample selected will be small and the ideas of the population were needed in a shorter period.

Data collection methods that will use include questionnaire. Analyzed quantitative data presented descriptively and illustrated by using tables and charts. The selections of these tools have been guided by the nature of data to be collected, which is based on the available time and the objectives of the study. Kothari ( Atkins, L., Francis, J., Islam, R., O’Connor, D., Patey, A., Ivers, N., ... \& Lawton, R. 2017 defines a questionnaire as a document that consists of a number of questions printed or typed in a definite order on a form or set of forms. And according to Dawson (2002), there are two basic types of questionnaires; closed ended and open-ended. Closed

(c) 2020 EPRA ARER | www.eprajournals.com ～Journal DOI URL: https://doi.org/10.36713/epra0813 
ended questionnaires are used to generate statistics in quantitative research while open-ended questionnaires are used in qualitative research, although some researchers quantify the answers during the analysis stage.

In development of a survey questionnaire, the variables for which information needs to be collected have to be identified followed by their operational definition. Primary data was collected through selfadministration of questionnaires to Somali Hope line Civil Society, Somali Peace Line. This study uses questionnaires to obtain quantitative data for analysis. Yang (2008) states that the questions in a study directly related to the research questions, Burns and Grove (2003) define data collection as the precise, systematic gathering of information relevant to the research problem, using methods such as participant observations, distribution of questionnaire, narratives and case histories. Kothari (2004) describes primary data as those which was collected afresh and for the first time, and thus intended to be original in character. Morrison et,al. (2007).

Testing reliability of the scale is very important as it shows the extent to which the scale produces steady results if the measurements are made repeatedly. This is done by determining the association in between scores obtained from different Local government on Nation building of the scale. If the association is high, the scale yields consistent results, thus it is reliable. Validity is the degree to which results the actually obtained analysis of the data represents the phenomena which is under study. It indicates how accurate the data obtained in the study represent the variables of the study (Mugenda \& Mugenda, 2003).

Data analyzing process can be helpful in better decision making for all the information of the evaluation relevant to the good governance (Silvia and Skilling, 2006). The data collected was analyzed using the software called Statistical Package for the Social Sciences (SPSS) version 20 and results shown in terms of frequency distribution and percentages. The data was tabulated and classified according to their common characteristics.

\subsection{DATA ANALAYSIS AND PRSENTATION RESULT}

This section tested the knowledge of the respondents on Capacity building of two youth organizations in Mogadishu, Somalia. Table 4.6 shows that the mean of respondents 1.01 agree that Capacity building is frequently pegged to efforts to redress disadvantage, health promotion, social and urban improvement and foster social change goals and 1.21 agree that Provision of capacity building to poor people can promote community development 1.85 agreed that Capacity building enables nonprofits organizations and their leaders to develop competencies and skills that can make them more effective and sustainable and 2.03 agreed that the Provision of capacity building does not associate nation building. The average mean score for the responses was 1.52 which indicates that many employees agreed to the Capacity building is frequently pegged to efforts to redress disadvantage, health promotion, social and urban improvement and foster social change goals. The findings agreed past study with those in Jian, Yang and Tsung (2011).

The second objective of the study was to determine the political participation of local government in Mogadishu. Table 4.7 shows that highest mean of respondents indicate 1.05 agree that Political participation is any activity that shapes, affects, or involves the political sphere and 1.25 agree It helps governments understand what it is that people want, and allows the people to make sure the government is fulfilling their role and 2.06 agreed that Political participation is when people get involved with the way in which their country is governed, and 2.32 agree that a Allowing citizens to have their voices heard is very important.. The average mean score for responses for this section was 1.66 which indicates that majority of the respondents agreed that effect of political participation is sometimes referred to as "rule of the majority.

The last objective of the study was to establish the Youth Leadership of two youth organizations in Mogadishu. Results on Table 4.8 indicate that highest of the respondents were 1.13 agreed that there has Youth leadership would start off by meaning selfleadership and 1.56 agreed that The youth leadership is important for them to develop the capability to develop one self And 1.64 agree that youth leadership would start off by meaning selfleadership. 2.01 Which indicates that majority of the respondents agreed that effect of Youth leadership is the practice of teens exercising authority over themselves or others.. The average mean score for the responses was 1.52 which indicates that there has been a high growth in the interest of youth becoming more involved in the communities in which they live.

\section{REGRESSION ANALYSIS}

In this study, a multiple regression analysis was conducted to test the role of youth participation on good governance at two selected organizations in Mogadishu, Somalia. The research used statistical package for social sciences (SPSS V 20) to code, enter and compute the measurements of the multiple regressions. 
Table: 4.12 Models Summery

\begin{tabular}{crrcc}
\hline & & & \multicolumn{3}{c}{ Std. Error of the } \\
Model & R & R Square & Adjusted R Square & Estimate \\
\hline 1 & & & & \\
\hline
\end{tabular}

Adjusted $\mathrm{R}$ squared is coefficient of determination which tells us the variation in the dependent variables due to change in the independent variables. From the findings in the above table the value of adjusted $\mathrm{R}$ squared is 0.564 and indicates that there was variation of $56.4 \%$ on good governance of two selected youth organizations in Mogadishu due to changes in capacity building, political participation and youth leadership at $95 \%$ confidence interval. This shows the significant that
$56.4 \%$ of the variations in the good governance at two selected youth originations in Mogadishu are accounted for by the variations in the independent variables and the remaining $43.6 \%$ are accounted by other factors contained in the standard error.

$\mathrm{R}$ is the correlation coefficient which shows the relationship between the study variables. From the findings shown in the table above there was a strongly positive relationship between the study variables as shown by 0.815 .

\section{ANALYSIS OF VARIATIONS}

Table: 4.13 ANOVA

\begin{tabular}{|c|c|c|c|c|c|c|}
\hline & Model & Sum Squares & df & Mean Square & $\mathbf{F}$ & Sig. \\
\hline \multirow[t]{3}{*}{1} & Regression & 25.547 & 3 & 8.516 & 28.263 & $.000^{\mathrm{a}}$ \\
\hline & Residual & 24.406 & 81 & .301 & & \\
\hline & Total & 49.953 & 84 & & & \\
\hline
\end{tabular}

From the ANOVA statistics shown in table, the processed data, which is the population parameters, had a significance level of $0.5 \%$ which shows that the data is ideal for making a conclusion on the population's parameter as the value of significance ( $\mathrm{p}$-value ) is less than $5 \%$. The $\mathrm{F}$ critical at $5 \%$ level of significance was 2.72 . Since F calculated (28.263) is greater than the $\mathrm{F}$ critical (2.72), this shows that the overall model was significant and that capacity building, political participation and youth leadership significantly affect the good governance of two selected youth organizations in Mogadishu- Somalia.

Table: 4.14 COEFFICIENTS

\begin{tabular}{lccccc}
\hline & \multicolumn{5}{c}{ Standardized } \\
Model & \multicolumn{6}{c}{ Un standardized Coefficients } & Coefficients & Sig. \\
\cline { 2 - 6 } B (Constant) & .903 & .364 & & 2.198 & .001 \\
Account receivable & .207 & .106 & .213 & 2.146 & .025 \\
Account payable & .416 & .093 & .443 & 4.462 & .000 \\
Cash Management & .174 & .073 & .216 & 2.508 & .012
\end{tabular}

From the data in the above table the established regression equation was;

$$
Y=0.903+0.207 X_{1}+0.416 X_{2}+0.174 X_{3}
$$

From the above regression equation it was revealed that holding capacity building, Political participation and Youth leadership to a constant zero, good governance of two youth organizations in Mogadishu would be at 0.903 . A unit change in capacity building would lead to increase in the good governance of two youth organizations in Mogadishu by a factor of 0.207. A unit increases in Political participation would lead to change in the good governance of two youth organizations in Mogadishu by a factor of 0.416 and a unit change in Youth leadership would lead to change in the good governance of two youth organizations in Mogadishu by a factor of 0.174 .

The regression results presented in above table indicate that capacity building, Political participation and Youth leadership were significant at 5 percent level. The coefficient of capacity building showed 0.207 with a p-value 0.025 , which is less than $5 \%$, the coefficient of Political participation was 0.416 which is less than 0.05 , with a p-value of 0.000 . And the coefficient of the Youth leadership was 0.174 , with a p-value of 0.012 which is less than 0.05 so that indicates there was statistically strong positive

(c) 2020 EPRA ARER ～～www.eprajournals.com ～Journal DOI URL: https://doi.org/10.36713/epra0813 
relationship between capacity building, Political participation and Youth leadership and good governance of two youth organizations in Mogadishu. Hence, the most significant factor is Political Participation. Overall, Political participation had the greatest effect on the good governance of youth organizations in Mogadishu, followed by Youth leadership and capacity building. All of the variables were found to be significantly affect good governance of youth organizations because they less than $(\mathrm{p}<0.05)$.

\subsection{Recommendations}

The study strongly recommended that all appropriate stakeholders should make a concerted effort to ensure that the different institutions of youth respect Somali youth rights and meet their needs and requirements by means of laws, rules policies, economic empowerment, up-skilling, procedures, standards, daily practices and national forums on equality to identify and develop strategies for dealing with the existing youth issues and concerns in higher educational institutions in order to increase youth participation in leadership positions.

$>$ Promote the concept of young people as assets and work towards the elimination of negative stereotypes of youth.

$>$ Promote the full and effective participation of young people at local, national, regional and international levels, with particular attention to marginalized youth.

$>$ Youth participation can also be improved through a number of approaches, such as education and capacity building. Youthfriendly information and materials can be developed with young people themselves, through both traditional and inclusive technology mediums, such as internet, SMS, etc. The material must be accessible to youth with disabilities.

$>$ Strengthen and develop public spaces and programmes in communities that are friendly to youth and allow intergenerational interaction.

$>$ Develop and implement regional and national policies and initiatives that address barriers to long term and sustainable youth employment, such as vocational training, in order to improve the transition from education to employment.

\section{REFERENCE}

1. Akpomi, M. E. (2008). Youth Participation among graduates-to-be of Business/Management faculties and economic development in Nigeria. European Journal of Economics, Financeand Administrative Sciences, 14, 52-61.

2. Angba, A. O., Adesope, O. M., \& Aboh, C. L. (2009). Effect of socioeconomic characteristics of rural youths on their attitude towards youth participation in community development projects, 4(8), 348-351

3. Ardichvili, A., Cardozo, R., \& Ray, S. (2003). A theory of cabacity building opportunity identification and development. Journal of Business Venturing, 18(1), 105-123.

4. Arthur, P. (2005). Promoting a youth leadership class in Ghana: The issues and problems. Canadian Journal of African Studies, 39(3), 427-459.

5. Aryeetey, E. (2001). Human capital development for socio-economic transformation. Ghana in the 21st Century ISSER Millennium Seminar Series, (8)

6. Avolio, B.J. \& Bass, B.M. (2004). Multifactor Leadership Questionnaire: Manual and sampler set (3rd ed.). Mind Garden

7. Bass, B.M. (1999). Two decades of research and development in transformational leadership. European Journal of Work and Organizational Psychology, 8(1), 9-

8. 32. Psychology Press Ltd

9. Brownell, J. (2010).Youth Leadership in the service hospitality. Cornell Hospitality Press

10. Clark, R.A., Hartline, M.D., \& Jones, K.C. (2009). The effects of leadership style Onhotel employees' commitment to service quality. Cornell Hospitality Quarterly,50(2), 209-231. DOI: 10.1177/1938965508315371

11. Botes, L \& Rensburg, D. van. (2000) "Community participation in development: nine plagues and twelve commandments". Community Development Journal, 35 (1): 41-58

12. Chan, C. G., \& Elder, G. H., Jr. (1999), Family influences on civic involvement. Unpublished manuscript cited in Fletcher et al, 2000.

13. Casswell, S. (2001). Community capacity building and social policy-what can be achieved? Social Policy Journal of New Zealand, (17), 2235. Retrieved from https://msd.govt.nz/documents/about-msd-andour-work/publications-resources/journals-andmagazines/social-policyjournal/spj17/17_pages22_35.pdf

14. Chess, C. \& Purcell, K. (2009), Youth participation and the environmental community projects: Do we know what works? Environmental Science and Technology 33 (16), 2685-2692.

15. Choguill, M.B. (1996). A ladder of community participation for underdeveloped countries. Habitat international, 20(3), 431-444.

16. Dike, V. E., \& Dike, N. I. (2017). Youth Development and Conflict Resolution in Nigeria: Assessment and Intervention Strategies. Asian Journal of Education and Training, 3(1), 30-42. https://doi.org/10.20448/journal.522/2017.3.1/52 2.1.30.42

17. Echevarría, L., Gómez, A., Piriz, C., Quintas, C., Tejera, R., \& Conde, D. (2013). Capacity building for local coastal managers: a participatory approach for Integrated Coastal and Marine Zones Management in Uruguay. Revista de Gestão Costeira Integrada, 13(4), 445-456. https://doi.org/10.5894/rgci402

18. Ekpe, I. (2017). Factors Impacting on Youth'S

(c) 2020 EPRA ARER ｜ www.eprajournals.com ～Journal DOI URL: https://doi.org/10.36713/epra0813 
EPRA International Journal of Agriculture and Rural Economic Research (ARER)- Peer-Reviewed Journal Volume: 8 | Issue: 6| December 2020| Journal DOI: 10.36713/epra0813|Impact Factor (SJIF): 7.367| ISSN: 2321 - 7847

Leadership Participation in Malaysia: Social Media, Social Groups or Government Policies? Polish Journal of Management Studies, 16(1), 21-31. https://doi.org/10.17512/pjms.2017.16.1.02

19. Jones, K. R. (2009). Influences of Youth Leadership within a Community-Based Context, 7(3), 246-264.

20. Mercy Corps. (2013). Examining the Links between Youth Economic Opportunity, Civic Engagement, and Conflict:; (January), 18.

21. Romanow, P., \& Bruce, D. (2006). Communication \& capacity building: Exploring clues from the literature for rural community development. Journal of Rural and Community Development, 1, 131-154.

22. Verity, F. (2007). Community Capacity Building - A review of the literature. Retrieved from http://www.health.sa.gov.au/PEHS/branches/heal th-promotion/0711-capacity-building-reviewlit.pdf 